\title{
Radiation-hard plastic scintillator with increased mechanical strength
}

\author{
P.N.Zhmurin, V.N.Lebedev, A.I.Bedrik, \\ V.D.Titskaya, A.F.Adadurov, E.Velmozhnaya \\ Institute for Scintillating Materials, STC "Institute for Single \\ Crystals",National Academy of Sciences of Ukraine, \\ 60 Lenin Ave., 61001 Kharkiv, Ukraine
}

\section{Received January 8, 2015}

\begin{abstract}
This paper describes possibilities of improving mechanical properties of radiation-hard plastic scintillator (PS) with additives by spatial cross-linking their polymer base. This allows improving the mechanical properties of the PS preserving their light yield and transparency. The cross-linked structure is formed in the PS matrix by copolymerization of the main monomer and cross-linking monomer which contains two active vinyl groups. 4,4'-Bis-(methylene-2-metacrylate)-biphenyl (BPBMA) was used as the cross-linking agent and derivatives of biphenyl and naphthalene as diffuse enhancers. Inserting the cross-linking agent and diffuse enhancers facilitate the increase of the PS mechanical strength retaining its functional properties.
\end{abstract}

Keywords: plastic scintillator, radiation hardness, mechanical strength.

Описываются возможности улучшения механических свойств радиационно-стойкого пластмассового сцинтиллятора с добавками при помощи пространственной сшивки его полимерной основы. Это позволяет улучшить механические свойства пластмассового сцинтиллятора, сохраняя его световой выход и прозрачность. Сшитая структура формируется в матрице сцинтиллятора в процессе сополимеризации основного мономера и сшивающего мономера, который содержит две активные винильные группы. 4,4'-Bis(methylene-2-metacrylate)-biphenyl (BPBMA), использовался в качестве сшивающего агента, а производные бифенила и нафталина - в качестве усилителей диффузии. Введение сшивающего агента и усилителей диффузии способствует увеличению механической прочности пластмассового сцинтиллятора при сохранении его функциональных свойств.

Радіаційно-стійкий пластмасовий сцинтилятор 3 підвищеною механічною міцністю. П.М.Жмурін, В.М.Лебедев, О.І.Бедрік, В.Д.Тітская, О.Ф.Ададуров, О.С.Вельможна.

Описано можливості поліпшення механічних властивостей радиаційно-стійкого пластмасового сцинтилятора 3 домішками за допомогою просторової зшивки його полімерної основи. Це дозволяє поліпшити механічні властивості пластмасового сцинтилятора, зберігаючи його світловий вихід і прозорість. Зшита структура формується в матриці сцинтилятора у процесі сополімеризації основного мономера и зшиваючого мономера, який містить дві активні вінільні групи. 4,4'-Bis-(methylene-2-metacrylate)biphenyl (BPBMA), використано у якості зшиваючого агента, а похідні біфенілу и нафталіну - у якості підсилювачів дифузії. Введення зшиваючого агента і підсилювачів дифузії сприяє підвищенню механічної міцності пластмасового сцинтилятора при збереженні його функціональних властивостей. 


\section{Introduction}

Modern high energy physics experiments require efficient plastic scintillators (PS) with increased radiation hardness and improved mechanical strength. These PS have to retain high scintillation efficiency and transparency to the self fluorescence light.

Polystyrene is the most radiation-hard and mechanically strong plastic base of the PS. But to add special properties to a scintillator, a large amount (20-40 wt. \%) of amorphous additives should be inserted to the polystyrene matrix. They usually degrade the mechanical properties of the material. This problem incidental to developing the PS with increased radiation hardness [1-3] and ability to neutron and gamma quanta discrimination by pulse shape $(n / \gamma$ discrimination) [4].

The most efficient way to create the radiation-hard polymer bases is the use of plasticizers (diffuse enhancers), which increase the mobility of the polymer chain fragments thus facilitating diffusion of atmospheric oxygen into the PS bulk. This leads to destruction of radicals formed in the PS material under ionizing radiation. Such diffuse enhancers usually are derivatives of naphthalene, biphenyl, and polyvinyloxides [2-5]. The best results were obtained with $20 \%$ of biphenyloxide. After irradiation by 2.8 Mrad dose this scintillation composition (trade mark UPS-98RH) retains $91 \%$ of the initial light yield, while the PS of traditional content (without diffuse enhancer) - UPS-923A - only $55 \%$ [6]. Therewith, the dose $\left(D_{1 / 2}\right)$, which decreases the light yield in a half, is rather small for UPS-923A $\left(D_{1 / 2}=1.2 \mathrm{Mrad}\right)$, and in more than four times greater for UPS98RH $\left(D_{1 / 2}=5.1 \mathrm{Mrad}\right)$.

Unfortunately, high content of the diffuse enhancer in the PS (20 wt. \%), results in strong plasticizing effect which leads to the PS material softening up to the plastic state (micro hardness HV $<50 \mathrm{MPa}$ ). Such a small mechanical strength hindered cutting and polishing of the PS material and promotes accelerated diffusion of the additives to the PS surface. This decreases the long-term stability and radiation hardness of the PS. Above drawbacks obstruct production, impair operation characteristics and limit the area of application of the radiation-hard PS with diffuse enhancers.

This paper describes possibilities of improving mechanical properties of the radiation-hard PS by spatial cross-linking their polymer base. This allows improving the mechanical properties of the PS preserving their light yield and transparency.

A cross-linked structure is formed in the PS matrix by copolymerization of the main monomer and cross-linking monomer which contains two active vinyl groups.

It was shown in [7-9], that the light yield of the cross-linked PS obtained by copolymerization of polystyrene and some derivatives of diacrylates, dimethacrylates, or diisopropenylbiphenyl, actually does not decreases. So, simultaneous inserting the cross-linking agent and plasticizer have to facilitate the increase of the PS mechanical strength retaining its functional properties.

\section{Experimental}

Polystyrene was used as a base of the radiation-hard PS with improved mechanical properties. It was purified by transmission through chromatographic column with aluminum oxide with further distillation under low pressure $(P=0.98$ bar $)$ and temperature $\left(85^{\circ} \mathrm{C}\right) . \quad 4,4^{\prime}$-Bis-(methylene-2metacrylate)-biphenyl (BPBMA) was used as the cross-linking agent and derivatives of biphenyl and naphthalene as diffuse enhancers. All they were synthesized in the Department of Plastic Scintillators, ISMA, NAS of Ukraine. 2,2'-Azobisisobutyronitrile (AIBN) from Aldrich was used as an initiator. It was purified by re-crystallizing from isopropyl alcohol. As scintillation additives, 2-(4-phenyl)-5-(4-biphenylyl)-oxadiazole-1,3 ,4 (PBD) and 1,4-bi(2-(5-phenyloxazolyl))benzene (POPOP) were used. These substances were produced in the State Plant for Chemical Reagents (Kharkov, Ukraine).

All above substances were selected according to one criterion: possibility of obtaining the firm cross-linked polymer with 25 wt. \% of diffuse enhancer. Besides, the PSs made on this base have to have light yield close to that of the PSs based on linear polystyrene. The studies have shown that cross-linking agent 4, $4^{\prime}$-bis-(metylen-2metacrylate)-biphenyl satisfies these conditions. It is possibly due to long monomer chain of BPBMA which allows rather large cells creating in the polymer bulk, which assists the dissolving of required quantity of the diffuse enhancer. Moreover, high compatibility of the polymer composition compounds is also connected with the high boiling temperature (about $300^{\circ} \mathrm{C}$ ) and low freezing point of alkyl substituted naphthalene and biphenyl. 
Table 1. Structural formulae, melting temperatures $\left(T_{\text {melt }}\right)$, boiling points $\left(T_{\text {boil }}\right)$ and fluorescence maxima $\left(\lambda_{\max }\right)$ of compounds used to obtain cross-linked radiation-hard PS

\begin{tabular}{||c|c|c|c|}
\hline Compound & Structural formula & $T_{\text {melt }},{ }^{\circ} \mathrm{C}$ & $\lambda_{\text {max }}, \mathrm{nm}$ \\
\hline $\begin{array}{c}\text { 4,4'-Bis-methylene-2-methacrylate- } \\
\text { biphenyl (BPBMA) }\end{array}$ & 85 & 320 \\
$\begin{array}{c}\text { 2-(4-Biphenylyl)-5-phenyl-1,3,4- } \\
\text { oxadiazole (PBD) } \\
\begin{array}{c}\text { 2,2'-(1,4-Phenylene)bis(5-phenyl- } \\
\text { 1,3-oxazole) (POPOP) }\end{array}\end{array}$ & & 104 & 365 \\
\hline
\end{tabular}

Structural formulae of all substances used for obtaining the cross-linked radiation-hard compositions are presented in Tables 1 and 2 .

Synthesis of $4,4^{\prime}$-bis-methylene-2methacrylate-biphenyl (BPBMA) was made according to the scheme 1 .

On the first stage, by means of biphenyl bromomethylation in the acetic acid with the presence of sodium bromide, paraformaldehyde and sulfur acid $4,4^{\prime}$ - dibrommethylbiphenyl is obtained [10]. On the second stage, in the dimethylphormamide medium with the potassium carbonate under $40^{\circ} \mathrm{C}$ temperature, the potassium salt of methacrylic acid is obtained. On the third stage, in the dimethylformamide medium, with the methyl alcohol presence, by means of reaction between 4 , $4^{\prime}$-dibrombiphenyl and potassium salt of methacrylic acid under $55^{\circ} \mathrm{C}$ temperature 4,4'-bis-(methylene-2metacrylate)-biphenyl (BPBMA) is obtained as colorless crystal powder. The measured absorption and luminescence spectra of the synthesized BPBMA are presented in Fig. 1,

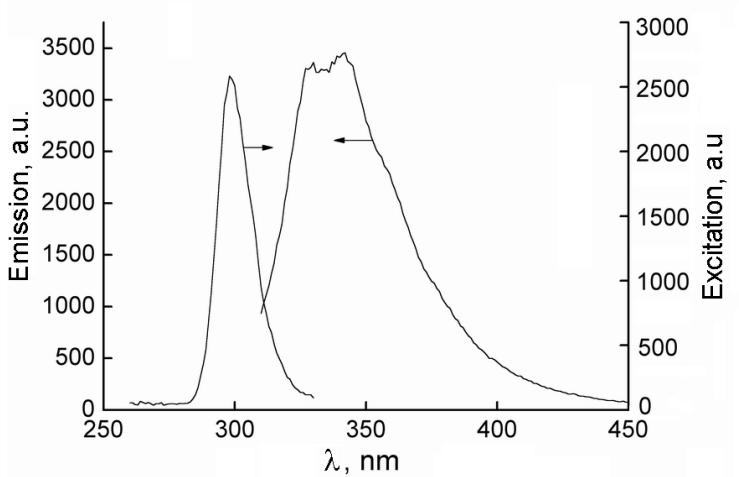

Fig. 1. Absorption and luminescence spectra of 4,4'-bis-(2-methylene-methacrylate) biphenyl.

from which it follows that they are close to the corresponding spectra of polystyrene. Therefore, this substance may be involved in the scintillation process.

Purification of 2,2'-azobisisobutyronitrile (AIBN) from impurities was performed by recrystallization from isopropanol. The melting point of purified AIBN is $103^{\circ} \mathrm{C}$.
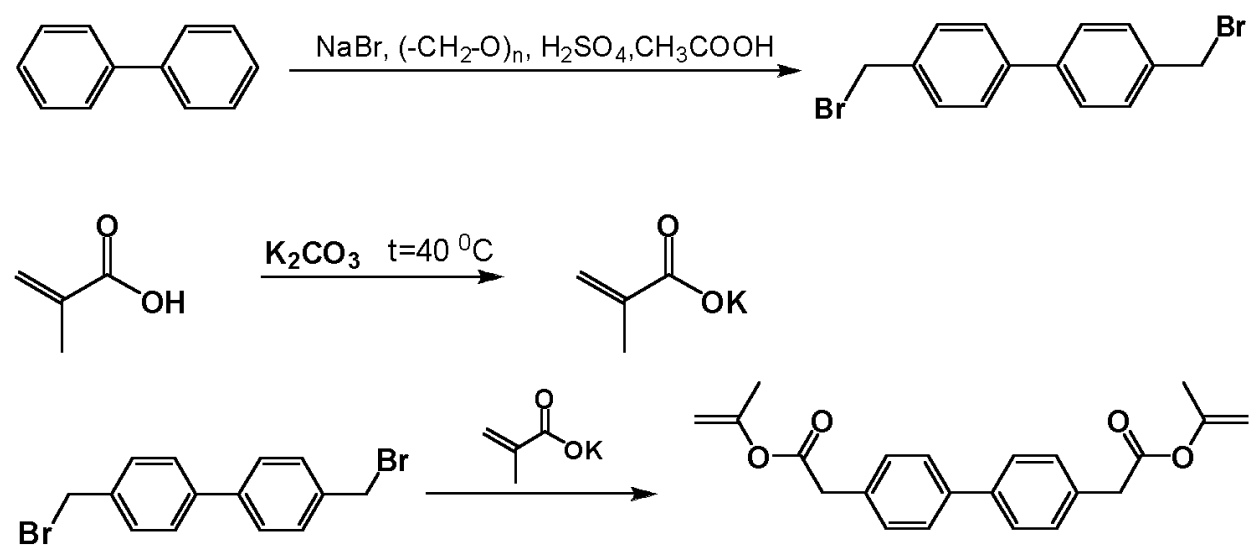

Scheme 1. 
Table 2. Structural and molecular formulae, boiling $\left(T_{b o i l}\right)$ and melting $\left(T_{\text {melt }}\right)$ temperatures of plasticizers

\begin{tabular}{|c|c|c|c|}
\hline Plasticizers & Structural formula & Molecular formula & $T_{\text {boil }},{ }^{\circ} \mathrm{C}$ \\
\hline 4-Isopropylbiphenyl (IPBP) & & $\mathrm{C}_{15} \mathrm{H}_{16}$ & 345 \\
\hline 1-Isopropylnaphthalene (IPN) & & $\mathrm{C}_{13} \mathrm{H}_{14}$ & - \\
\hline $\begin{array}{l}\text { 1,6-Diisopropylnaphthalene } \\
\text { (DIPN) }\end{array}$ & & $\mathrm{C}_{16} \mathrm{H}_{20}$ & 306 \\
\hline 1-Methylnaphthalene (MN) & & $\mathrm{C}_{11} \mathrm{H}_{10}$ & 244 \\
\hline $\begin{array}{l}\text { 1,6-Dimethylnaphthalen } \\
\text { (DMN) }\end{array}$ & & $\mathrm{C}_{12} \mathrm{H}_{12}$ & 264 \\
\hline
\end{tabular}

Preparation of the samples of spatially cross-linked radiation-hard PS was performed by the copolymerization of styrene monomer with 4,4-bis (2-methylene-methyl) - diphenyl (BPBMA) in the presence of the plasticizer (diffusion enhancer) and the polymerization initiator AIBN. Concentration of the cross-linking agent BPBMA in various samples was ranged from 3 to 15 wt. \%. Content of the other additives remained constant: the diffusion enhancer - 25 wt. \%, the polymerization initiator $(\mathrm{AIBN})-0.02$ wt. $\%$, the primary fluorescent additive (PBD) 2 wt. $\%$, the secondary fluorescent additive (POPOP) - 0.1 wt. $\%$.

Prepared reaction mixtures with different contents of the cross-linking agent were placed in glass vials in amount of $10 \mathrm{~g}$ and dissolved at temperature $65^{\circ} \mathrm{C}$. To remove oxygen traces, the reaction mixture was saturated by argon for 10 min., the vials were sealed and mounted in the thermostat. Polymerization was carried out by stepwise temperature-time mode with temperature rise from 65 to $150^{\circ} \mathrm{C}$ for $150 \mathrm{~h}$ and subsequently cooled with $5^{\circ} \mathrm{C}$ per hour rate. As a result the solid, colorless and transparent preforms were obtained from which the PS samples were made as polished cylinders of $16 \mathrm{~mm}$ diameter and of $10 \mathrm{~mm}$ height.

Mechanical properties of the samples were evaluated by the value of material microhardness, while scintillation properties
- by the light output. Microhardness was determined by the Vickers Hardness method with PMT-3 microhardnessmeter. The light output was measured by a scintillation spectrometer, performed in the CAMAC standard, using a photomultiplier Hamamatsu R1307 and ${ }^{207} \mathrm{Bi}$ source of electrons. The light output is measured relative to the "standard" PS UPS-923A, which is made on the basis of linear polystyrene and contains two fluorescent additives ( $2 \%$ of para-terphenyl and $0.1 \%$ of POPOP).

The measurement results are shown in Fig. 2-4. Fig. 2 shows the dependence of microhardness of the radiation hard PS with linear structure (without any crosslinking agent) on the plasticizer (IPBP) content. As it is seen in the figure, when the content of IPBP is varied from 0 to $5 \mathrm{wt}$. \%, microhardness of the PS material varies slightly from 124 to $120 \mathrm{MPa}$, which corresponds to the microhardness of the pure polystyrene. With increasing the plasticizer content up to $10 \mathrm{wt} \%$, the microhardness decreases slowly, but at content of 20 wt. \% microhardness is dramatically reduced to $38 \mathrm{MPa}$, which corresponds to viscous flowing state, and at 25 wt. $\%$ it falls to $2 \mathrm{MPa}$.

Figure 3 shows a dependence of microhardness of the PS with 25 wt. \% of various plasticizers, on the amount of crosslinking agent, i.e. the degree of the polymer "stitching". This figure demonstrates that 


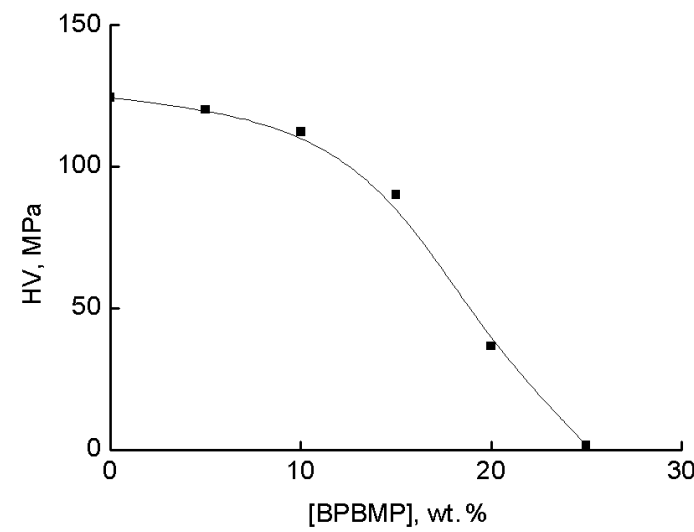

Fig. 2. Dependence of microhardness of radiation hard PS with linear structure (without cross-linking agent) on content of the plasticizer (IPBP).

with increase of the cross-linker content from 3 to $15 \mathrm{wt}$. \% the great increase of microhardness is obtained, regardless of the type of used plasticizer.

It is seen in the figure that when the content of the cross-linking agent BPBMA is 3 wt. \%, microhardness of all samples varies from 2 to $11 \mathrm{MPa}$, which corresponds to the plastic, rubbery-like state. It is also seen that with increasing the cross-linker content from 7 to 10 wt. \% microhardness increases faster for the samples in DIMN, IPBP, IPN, DIPN, MN series. Thus, when $[\mathrm{BPBMA}]=10$ wt. $\%$, microhardness of these samples is $67,59,45,32$ and $13 \mathrm{MPa}$, respectively, and for the DIMN sample virtually reaches its limit $(70 \mathrm{MPa})$. The microhardness of the remaining samples continues to grow with increase of the content of the cross-linking agent, and when $[\mathrm{BPBMA}]=15 \mathrm{wt} . \%$ it is close to $70 \mathrm{MPa}$ for all samples. This corresponds to the hardness sufficient for material machining (cutting and polishing at the room temperature).

Here we should note that the average microhardness of the polyvinyltoluene based PS BC-408 is $105 \mathrm{MPa}$, and for the polystyrene-based PS UPS-923A it is $122 \mathrm{MPa}$. Also it should be noted that these values were obtained within 2 months from the date of manufacture of the PS, because the microhardness of the PS increases in time because of the natural aging processes. Thus, our measurements showed that after 6 months the microhardness of UPS-923A and BC-408 increases from $120-130$ to $160-$ $170 \mathrm{MPa}$ and from $100-110$ to $130-140$ $\mathrm{MPa}$, respectively.

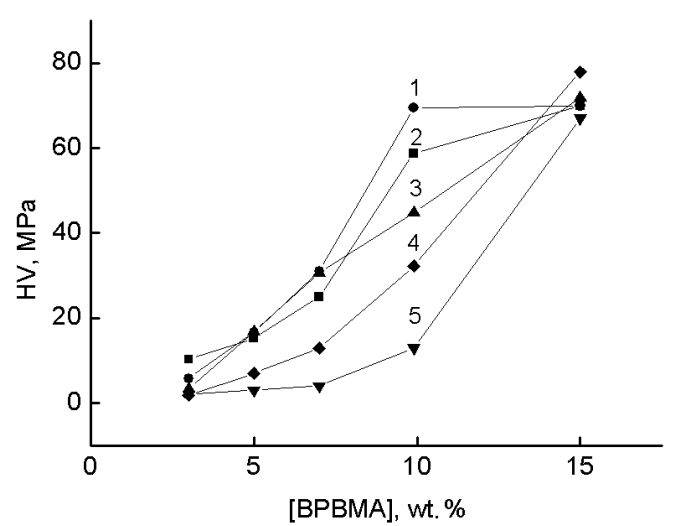

Fig. 3. Dependences of microhardness of PS with 25 wt. $\%$ of various plasticizers $(1-$ DMN, $2-$ DIPN, 3 - IPBP, $4-$ IPN, $5-$ $\mathrm{MN}$ ) on content of the cross-linking agent BPBMA. For reference-microhardness of the standard UPS-923A is $122 \mathrm{MPa}$.

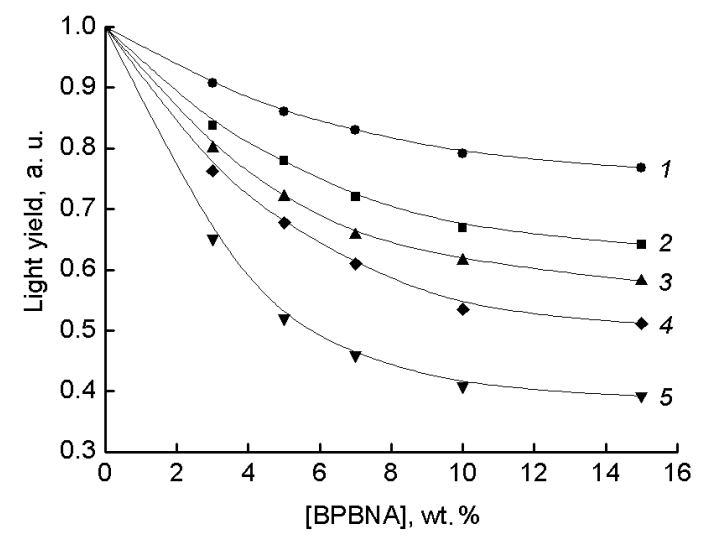

Fig. 4. Relative light output of PS with $25 \%$ wt $\%$ of plasticizer $(1-$ IPN, $2-$ IPBP, $3-\mathrm{MN}, 4-\mathrm{DIPN}, 5-\mathrm{DMN}) \mathrm{de}-$ pending on content of the cross-linking agent BPBMA.

Relative light output was measured on the PS with different content of the crosslink agent BPBMA and 25 wt. \% of various plasticizers. Results are shown in Fig. 4. It is seen that the light output of the PS is significantly reduced by increasing the BPBMA content. The PSs with isopropylnaphthalene (IPN) as a diffusion enhancer retain the largest light output. When the content of the cross-linking agent is $15 \mathrm{wt} . \%$, the light output of this PS is 0.77 , and the light output of the PS from IPBP, MN, DPN and DMN series decreases and equals to $0.64,0.58,0.51$ and 0.39 , respectively, with respect to the PS of linear structure (without cross-link agent). 


\section{Conclusions}

Thus, mechanical strength of the PS material with up to $25 \%$ wt. \% plasticizers IPBP, IPN, DIPN, MN, DMN can be increased by cross-linking the polymer matrix. Thus, use of $10-15$ wt. $\%$ of a $4,4^{\prime}$-bismethylene-2-methacrylate-biphenyl as a cross-linking agent allows increasing the mechanical strength of the PS material with any of the above-mentioned plasticizers up to $70 \mathrm{MPa}$ and higher. The highest light yield of 0.76 and microhardness of $78 \mathrm{MPa}$ are provided in the composition that contains $25 \mathrm{wt} \%$ of isopropylnaphthalene in combination with $15 \mathrm{wt} \%$ of cross-link agent $\quad 4,4^{\prime}$-bis-methylene-2-methacrylatebiphenyl.

This work was supported by the Foundation for Fundamental Research of Ukraine.

\section{References}

1. F.Markley, D.Woods, A.Pla-Dalmau, G.Foster, Radiat. Phys. Chem., 41, 135 (1993).

2. F.Markley, V.Senchishin, V.Lebedev et al., Nucl.Instr. Meth. Phys. Res., A364, 253 (1995).

3. V.G.Senchishin, V.N.Lebedev, A.F.Adadurov et al., Functional Materials, 10, 281 (2003).

4. P.N.Zhmurin, V.N.Lebedev, V.D.Titskaya et al., Nucl.Instr. Meth. Phys. Res. A, 92 (2014).

5. N.H.Khlapova, V.G.Senchyshyn, V.N.Lebedev, A.F.Adadurov, Probl. Atomic Sci. and Techn., Ser.: Nucl. Phys. Investig., 47, 142 (2006).

6. B.V.Grinyov, V.G.Senchyshyn, Plastic Scintillators, Acta, Kharkov (2003) [in Russian].

7. U.S. Patent 4495084 (1985).

8. T.Kamon, K.Kondo, A.Yamashita, Nucl.Instr. Meth. Phys. Res., 213, 216 (1983).

9. Author's certificate USSR 1334958 (1989).

10. Ukraine Patent 33555 (2001). 